\title{
Public policies in headache disorders: needs and possibilities
}

\author{
Políticas públicas em cefaleias: necessidades e possibilidades \\ Mario Fernando Prieto PERES ${ }^{1,2,34}$, Arao Belitardo OLIVEIRA ${ }^{1,2,3,4}$, Elder Machado SARMENTO3,5, \\ Pedro Sampaio ROCHA-FILHO,,6, Patricia Machado PEIXOTO3,7, Fernando KOWACS $8,9,10$, \\ Alessandra Carvalho GOULART ${ }^{11,12}$, Isabela Martins BENSEÑOR ${ }^{11,12}$
}

\begin{abstract}
Although headaches have recognized impact, there are no public policies in Brazil addressing this problem. The Brazilian Headache Society and the Brazilian Association of Cluster Headache and Migraine promoted a summit to discuss Public Policy and Advocacy for headache disorders. Professionals from various segments, representing various sectors of society, gathered in April 2019 in Brasília, defining the most important points for achieving advances in public policies in headache in Brazil, such as: inclusion in the chronic diseases surveillance agenda; improving public understanding and access to diagnosis and treatment; teaching in colleges and medical residences, structuring care networks, intervention models, clinical protocols and legislation supporting public policies in headache.
\end{abstract}

Keywords: headaches; migraine; public policies.

RESUMO

Embora as cefaleias tenham reconhecido impacto, não há no Brasil políticas públicas voltadas para este problema. A Sociedade Brasileira de Cefaleia e Associação Brasileira de Cefaleia e Enxaqueca promoveram um seminário para a discussão de Políticas Públicas e Advocacy (defesa dos direitos dos pacientes) em Cefaleias. Reuniram-se em abril de 2019 em Brasília, profissionais de vários segmentos, representando diversos setores da sociedade, definindo os pontos mais importantes para que se obtenham avanços nas políticas públicas em cefaleias no Brasil, tais como: inclusão na agenda de vigilância das doenças crônicas não transmissíveis; melhora do entendimento do público e seu acesso a diagnóstico e tratamento; ensino em faculdades e residências médicas, estruturação de redes de atendimento, modelos de intervenção, protocolos clínicos e legislação de apoio às políticas públicas em cefaleia.

Palavras-chave: cefaleias; enxaqueca; políticas públicas.

Primary headaches are among the three most prevalent neurological diseases in the world, according to the World
Health Organization ${ }^{1}$. Tension-type headache affects 1.5 billion individuals, and migraine 958.8 million. Medication

${ }^{1}$ Hospital Israelita Albert Einstein, São Paulo SP, Brazil.

${ }^{2}$ Universidade de São Paulo, Faculdade de Medicina, Hospital das Clínicas, Instituto de Psiquiatria, São Paulo SP, Brazil.

${ }^{3}$ Sociedade Brasileira de Cefaleia, Barra Mansa RJ, Brazil.

${ }^{4}$ Associação Brasileira de Cefaleia em Salvas e Enxaqueca, São Paulo SP, Brazil.

${ }^{5}$ Universidade Federal Fluminense, Rio de Janeiro RJ, Brazil.

${ }^{6}$ Universidade Federal de Pernambuco, Departamento de Neuropsiquiatria, Recife PE, Brazil.

${ }^{7}$ Secretaria de Saúde do Distrito Federal, Brasília DF, Brazil.

${ }^{8}$ Hospital Moinhos de Vento, Serviço de Neurologia e Neurocirurgia, Porto Alegre RS, Brazil.

'Universidade Federal de Ciências da Saúde de Porto Alegre, Irmandade Santa Casa de Misericórdia, Serviço de Neurologia, Porto Alegre RS, Brazil.

${ }^{10}$ Departamento Científico de Cefaleia da Academia Brasileira de Neurologia, São Paulo SP, Brazil.

${ }^{11}$ Universidade de São Paulo, Hospital Universitário, São Paulo SP, Brazil.

${ }^{12}$ Universidade de São Paulo, Centro de Pesquisa Clínica e Epidemiológica, Hospital Universitário, São Paulo SP, Brazil.

Mario Fernando Prieto PERES (ID) https://orcid.org/0000-0002-0068-1905; Arao Belitardo OLIVEIRA (iD) https://orcid.org/0000-0001-6408-0634; Elder Machado SARMENTO ID https://orcid.org/0000-0003-4500-1376; Pedro Sampaio ROCHA-FILHO iD https://orcid.org/0000-0001-5725-2637; Fernando KOWACS (iD https://orcid.org/0000-0002-0407-407X;Alessandra Carvalho GOULART iD https://orcid.org/0000-0003-1076-5210; Isabela Judith BENSENOR iD https://orcid.org/0000-0002-6723-5678

Correspondence: Mário Fernando Prieto Peres; Hospital Israelita Albert Einstein; R Joaquim Eugenio de Lima, 881; 05652-900 São Paulo SP, Brazil; E-mail: mariop3r3s@gmail.com

Conflict of interest: There is no conflict of interest to declare.

Received on August 20, 2019; Received in its final form on September 16, 2019; Accepted on September 23, 2019. 
Overuse Headache (MOH) affects another 58.5 million people around the world ${ }^{1}$. These three conditions account for $17 \%$ of the global impact of all neurological diseases, with migraine, despite not causing an increase in mortality, is considered the second most disabling disease $\mathrm{e}^{1,2}$. Including in this estimate individuals suffering from $\mathrm{MOH}$ - originally mostly migraine - it becomes the first cause of disability from 15 to 49 years of age, during a period of high professional, family and social productivity ${ }^{3}$.

Cluster headache, considered the most severe among primary headaches, and even worse than the pain in conditions such as renal colic, pancreatitis, and labor ${ }^{4-6}$, is associated with severe disability in $80 \%$ of patients ${ }^{7}$. Nevertheless, the diagnosis is established on average only seven to eight years after the first episode ${ }^{8}$.

Although there are several effective treatment options for most patients with any major primary headache, access to trained professionals in this area is limited, making it difficult to establish the correct diagnosis and proper management in most cases $^{6-10}$.

Formally, it is acknowledged that the prospects for the care of primary headache sufferers in Brazil depend predominantly on $74 \%$ coverage of the SUS (Unified Health System) ${ }^{11}$, that there is a need for public managers to be aware of the headache, and that implementation of educational strategies and public policies are fundamental. On April 27, 2019, professionals from various segments gathered in Brasília, representing various sectors of society: doctors, researchers, patients, representatives of government agencies for the first summit specifically dedicated to public policies in the area of headache in Brazil.

This forum was organized by SBCe (Brazilian Headache Society) and ABRACES (Brazilian Association of Cluster Headache and Migraine [Headache Advocacy Association]). Topics presented and discussed included: epidemiological data and studies of headaches in Brazil, advocacy for headache patients in Brazil, experiences of training primary care teams in headache care, public policy experiences and advocacy in other diseases (mental health, cancer, multiple sclerosis), experience of primary health care / family health strategy, and the role of ANVISA.
The discussion during the Summit led to a consensus statement that it is necessary and important to:

- Include primary headaches in the non-communicable disease surveillance agenda.

- Improve public understanding of headaches and reduce their stigma through awareness-raising campaigns and monitoring of painkillers' advertising.

- $\quad$ Provide patients with primary headaches adequate access to necessary medical care.

- $\quad$ Encourage the teaching of headache in undergraduate medical courses.

- Encourage the teaching of headaches and their inclusion in the syllabus of medical residences, especially in neurology, medical clinic, gynecology and obstetrics, pediatrics, and family medicine.

- $\quad$ Provide health care professionals with access to headache training.

- $\quad$ Structure a public sector headache care network at the primary, secondary, and tertiary levels.

- Identify the current percentage of patients diagnosed, treated and in remission, with cluster headache and episodic or chronic migraine and set goals to be achieved in two, five, and ten years regarding the proper diagnosis and treatment of these headaches after implantation, interventions, and planned improvements.

- Write the clinical protocols and therapeutic guidelines for cluster and other headache, as well as specific situations that may require special management.

- $\quad$ Propose and pass laws for public policies defined in the area of headache.

\section{CONCLUSION}

The Brasília Declaration sets out the most important points for achieving advances in public policies in headache disorders in Brazil, as a milestone in the beginning of a joint work to improve knowledge, both by the population and health professionals about primary headaches, and the care dedicated to those who suffer from these health problems and who are treated in the public health system.

\section{References}

1. GBD 2015 Neurological Disorders Collaborator Group. Global, regional, and national burden of neurological disorders during 1990-2015: a systematic analysis for the Global Burden of Disease Study 2015. Lancet Neurol. 2017 Nov;16(11):877-97. https://doi. org/10.1016/S1474-4422(17)30299-5

2. World Health Organization. Global Health Estimates 2018: Disease burden by Cause, Sex, by Country and Region, 2000-2016. Geneva: WHO; 2018.

3. Steiner TJ, Stovner LJ, Vos T, Jensen R, Katsarava Z. Migraine is first cause of disability in under 50 s: will health politicians now take notice? J Headache Pain. 2018 Feb;19(1):17. https://doi.org/10.1186/ s10194-018-0846-2
4. Rozen TD. Cluster headache as the result of secondhand cigarette smoke exposure during childhood. Headache. 2010; Jan;50(1):130-2. https://doi.org/10.1111/j.1526-4610.2009.01542.x

5. Bahra A, May A, Goadsby PJ. Cluster headache: A prospective clinical study with diagnostic implications. Neurology. 2002 Feb;58(3):35461. https://doi.org/10.1212/wnl.58.3.354

6. Bahra A, Goadsby PJ. Diagnostic delays and mis-management in cluster headache. Acta Neurol Scand. 2004;109(3):175-9. https://doi. org/10.1046/j.1600-0404.2003.00237.x

7. van Kleef M, Lataster A, Narouze S, Mekhail N, Geurts JW, Van Zundert J. 2. Cluster Headache Pain Pract. 2009 Nov/Dec;9(6):43542. https://doi.org/10.1111/j.1533-2500.2009.00331.x 
8. Jurno M, Pereira BSR, Fonseca FAS, Teixeira GA, Maffia LQ, Barros MRA, et al. Epidemiologic study of cluster headache prevalence in a medium-size city in Brazil. Arq Neuropsiquiatr. $2018 \mathrm{Jul} ; 76(7)$ :46772. http://dx.doi.org/10.1590/0004-282×20180065

9. Dodick DW, Loder EW, Manack Adams A, Buse DC, Fanning KM,

Reed ML, et al. Assessing barriers to chronic migraine consultation, diagnosis, and treatment: Results from the Chronic Migraine Epidemiology and Outcomes (CaMEO) study. Headache. 2016 May;56(5):821-34. http://dx.doi.org/10.1111/head.12774
10. Lipton RB, Serrano D, Holland S, Fanning KM, Reed ML, Buse DC. Barriers to the diagnosis and treatment of migraine: Effects of sex, income, and headache features. Headache. 2013 Jan;53(1):81-92. http://dx.doi.org/10.1111/j.1526-4610.2012.02265.x

11. Brasil. Ministério da Saúde. Secretaria de Atenção à Saúde. Departamento de Atenção Básica. Diretrizes para o cuidado das pessoas com doenças crônicas nas redes de atenção à saúde e nas linhas de cuidado prioritárias. Brasília: Ministério da Saúde, Departamento do Atenção Básica; 2013 